\title{
Correction to: Psychometric properties of the Arabic version of the Basic Psychological Needs Satisfaction-Frustration Scale (BPNSFS)
}

\author{
Kashef N. Zayed ${ }^{1 *}$, Ehab N. Omara', Nasser Y. al-Rawahi ${ }^{2}$, Ali K. al-Shamli ${ }^{3}$, Asama A. al-Atiyah², \\ Ahmad A. al-Haramleh ${ }^{4}$, Mahmoud S. Azab ${ }^{5}$, Ghada M. al-Khasawneh ${ }^{6}$ and Mohammed A. Hassan ${ }^{7}$
}

\section{Correction to: BMC Psychol (2021) 9:15 https://doi.org/10.1186/s40359-020-00506- 1}

Following publication of the original article [1], the authors flagged that the article had published with incorrect affiliation details and with the name of the fifth author misspelled as 'Asama K. al-Attiyah' rather than 'Asama A. al-Atiyah'.

The original article has since been updated and the corrected affiliations details and author list can be found in this correction article.

\footnotetext{
Author details

${ }^{1}$ Sultan Qaboos University, Muscat, Oman. ${ }^{2}$ Qatar University, Doha, Qatar. ${ }^{3}$ Suhar University, Sohar, Oman. ${ }^{4}$ Hafr Al-Batin University, Hafar Al Batin, Kingdom of Saudi Arabia. ${ }^{5}$ Yarmouk University, Irbid, Jordan. ${ }^{6}$ Palestine Technical



Published online: 10 May 2021

\section{Reference}

1. Zayed KN, Omara EN, Al-Rawahi NY, et al. Psychometric properties of the Arabic version of the Basic Psychological Needs Satisfaction-Frustration Scale (BPNSFS). BMC Psychol. 2021;9:15. https://doi.org/10.1186/ s40359-020-00506-1.

The original article can be found online at https://doi.org/10.1186/s40359020-00506-1.

*Correspondence: kashefz@squ.edu.om

1 Sultan Qaboos University, Muscat, Oman

Full list of author information is available at the end of the article

\section{Publisher's Note}

Springer Nature remains neutral with regard to jurisdictional claims in published maps and institutional affiliations.

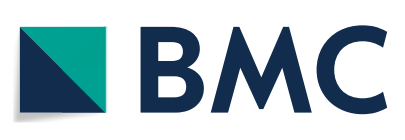

(c) The Author(s) 2021. Open Access This article is licensed under a Creative Commons Attribution 4.0 International License, which permits use, sharing, adaptation, distribution and reproduction in any medium or format, as long as you give appropriate credit to the original author(s) and the source, provide a link to the Creative Commons licence, and indicate if changes were made. The images or other third party material in this article are included in the article's Creative Commons licence, unless indicated otherwise in a credit line to the material. If material is not included in the article's Creative Commons licence and your intended use is not permitted by statutory regulation or exceeds the permitted use, you will need to obtain permission directly from the copyright holder. To view a copy of this licence, visit http://creativecommons.org/licenses/by/4.0/. The Creative Commons Public Domain Dedication waiver (http://creativeco mmons.org/publicdomain/zero/1.0/) applies to the data made available in this article, unless otherwise stated in a credit line to the data. 